\title{
On the Impact of Bond's Rating Changes on the Firm's Stock Price
}

\author{
Gil Cohen ${ }^{1}$ \\ ${ }^{1}$ Carmel Academic Center, Haifa, Israel \\ Correspondence: Gil Cohen, Head of the Finance and Banking Track, Carmel Academic Center, Haifa, Israel. E-mail: \\ gilc@yvc.ac.il \\ Received: October 28, 2013 \\ Accepted: November 14, $2013 \quad$ Online Published: January 10, 2014 \\ doi:10.5430/ijfr.v5n1p64 \\ URL: http://dx.doi.org/10.5430/ijfr.v5n1p64
}

\begin{abstract}
In the following research I have studied how bond rating changes that was conducted by Israel leading rating agency is affecting the firm's stocks abnormal returns. In order to do so I have examined 9 bonds upgrades and 9 downgrades from December 2012 until October 2013. For each of the stocks I have calculated three times abnormal return 30 days before and 60 days after the event. Results show that bond's rating downgrades has a more significant effect on the socks abnormal return than upgrades. This is especially true for bonds that were downgraded from Lower-medium grade to Non- Investment grade. Moreover, the downgrade effect on the stock price is diminishing after 45 days.
\end{abstract}

Keywords: bonds rating, abnormal return, rating agencies, yields

\section{Introduction}

Credit rating agencies have an important role in the financial markets. From time to time they change the firm's bond ratings and by doing so they announce an increase or a decrease of the financial risk involved in the company. A negative change of the firm's credit rating would cause a decline in its bond prices and elevate its yields to maturity (Note 1). On the other hand, a positive rating change should increase the firm's bonds prices while decreasing their yields. The question raised here is do stocks react the same to bonds rating changes. Should a stock investor expect a positive abnormal return after bond rating upgrade and a negative abnormal return when the bonds are downgraded?

Rating changes and their influence on the financial markets have been Studied and documented. Weinstein (1997) indicates that over $50 \%$ of rating changes result from reviews accompanying new debt issue. Kaplan and Urwitz (1979) supports the claim that rating agencies react to information which is already publicly available. Pinches and Singleton (1978) found that the information contained in bond rating changes is impounded into the stock price up to one year in advance of the rating change. Beaver et al. (2006) and Griffin and Sanvicente (1982) found a significant negative price response for downgrades using monthly stock return data. On the other hand, other researchers such as Wakeman (1978) found no evidence of a price response to rating changes. In the following study I have examined to what extent bond rating changes have an impact on the relevant stocks short term abnormal return utilizing bond rating changes made by "Malot" rating agency (Note 2). To the best of my knowledge no such a research have ever been using data extract from the Israeli financial markets linking bond rating to stocks returns. Moreover my research should strengthen or weaken prior researches concerning the impact of rating changes in the credit market on stocks behavior.

\section{Background Literature Review}

The roll of the rating agencies is to improve efficiency in the credit market reducing information gaps between investors and issuers in that market. Debt rating is commonly used in performance pricing agreements, where interest rates vary according to the firm's performance (Asquith et al. (2005), Doyle (2004)). Moreover, in some countries regulations enable institutional investors to hold bonds that are rated as investment- grade by certified agency (Cantor and Packer (1995)). In 2010 the Israeli government has adopted "Hodeck" (Note 3) committee recommendation in order to improve institutional investment in corporate bond. One of the most important recommendations was an automatic interest rate increase in case of rating downgrading of the bond. In The U.S the government adopted procedures that recognize the ability of the rating agency to produce an accurate risk measurement. That recognition has valuated as most important by researchers such as Hunt (2002) and Borrus (2002) to produce a reliable ratings. The question to what extent regulations of the rating agencies market is necessary has 
been presented for example by Djankov et al. (2002). That literature debates the necessity to limit the amount of rating agencies that operates in a specific credit market. Limiting the amount of rating agencies may support their profit bottom line and may reduce pressure that might be inquired by issuers. On the other hand, limiting the amount of rating agencies can lead to reduced sensitivity of the agencies to investor's needs. An inherent known problem with the rating process is the fact that most rating agencies are paid by the issuer of the bond creating pressure on the rating agency to inflate their rating. Bolton, Freixas, and Shapiro(2012) and Camanho, Deb, and Liu (2010) have showed that rating agencies that face tougher competition are more likely to issue inflated rating. The tendency to inflated rating is associated with more complex securities (Mathis, McAndrews, and Rochet (2009)) or when ratings are issued during a boom period (Bar-Issac and Shapiro (2012)). Becker and Milbourn (2011) showed that competition among rating agencies during 1995-2006 is positively correlated to the credit ratings of firms. They interpret this result as evidence that increased competition leads to rating inflation in corporate bond markets due to potential conflicts of interest among rating agencies. Bongaerts, Cremers, and Goetzmann (2012) showed that the inflated rating phenomena increases when issuer shop for around for favorable rating.

Xia (2012) has examined the quality of the rating process performed by competitors' agencies when an investor-paid rating agency (Egan- Jones rating company) has entered the market. He finds that ratings were shifted downwards and that they better reflect market risks. In the Israel credit markets two rating agencies operates. "Maalot" which is the senior rating agency and a subsidiary of S\&P and "Midrug" which is a subsidiary of Moody's international (Note 4). In the following research I examined the impact of "Maalot" corporate bond rating changes on the firm's stocks.

\section{Data, Modeling and Results}

From December 2012 until October 2013 "Maalot" has issued 42 rating changes (Note 5). 12 are rating upgrades and 30 downgrades. Out of the 42 rating changes, only 34 firms have also a stock that is traded on the Israeli stock market (9 rating upgrades and 25 downgrades). It is worth to acknowledge that statistically rating agencies downgrades bonds more frequently than upgrades them. Watts (1977) for example, points out that rating agencies tends to be more conservative because the costs from losses due to overvaluation are greater than the foregone gains due to undervaluation, i.e., downgrades are more important than upgrades. He also argued in a later paper (Watts (2003)) that rating agencies will incorporate bad news sooner than good news concerning the firm's ability to support their bonds obligations.

In the following research I have followed 18 stock abnormal returns (9 rating upgrades and 9 downgrades) one month prior to the rating change and two months after in order to establish whether a short term stock abnormal return can be achieved. First, I calculated the systematic risk "Beta" (Note 6) using 12 and 36 months weekly returns of the stock and the benchmark which is Tel Aviv 100 index. I have double calculated the "Beta" in order to make sure that systematic risk changes do not distort my results. Second I have calculated for each stock three Cumulative Abnormal Returns (CAR) using the following equations:

$$
C A R 1=\sum_{1}^{n} R s-R M
$$

When: Rs= daily stock return and RM is Tel Aviv 100 daily return

$$
C A R 1,2=\sum_{1}^{n} R s-R(C A P M)
$$

When: Rs= daily stock return and R(CAPM) the daily required return according to the CAPM model using 12 or 36 month "Beta".

I have separated the calculated CAR into two period 30 days before the rating change ("the event") and 60 days after. Table 1 summarizes the results for the 9 examined upgrades. 
Table 1. Cumulative abnormal return (\%) 30 days before and 60 days after credit rating upgrade

\begin{tabular}{|c|c|c|c|c|c|c|c|c|c|c|}
\hline & Stock & $\begin{array}{l}\text { Upgrades } \\
\text { From- } \\
\text { to } \\
\end{array}$ & \begin{tabular}{l}
\multicolumn{1}{c}{12} \\
months \\
Beta
\end{tabular} & $\begin{array}{l}36 \\
\text { months } \\
\text { Beta }\end{array}$ & $\begin{array}{l}\text { Before } \\
\text { simple } \\
\text { CAR }\end{array}$ & $\begin{array}{l}\text { After } \\
\text { simple } \\
\text { CAR }\end{array}$ & $\begin{array}{l}\text { Before } \\
12 \quad M \\
\text { Beta } \\
\text { CAR }\end{array}$ & $\begin{array}{l}\text { After } \\
12 \mathrm{M} \\
\text { Beta } \\
\text { CAR } \\
\end{array}$ & $\begin{array}{l}\text { Before } \\
36 \quad M \\
\text { Beta } \\
\text { CAR } \\
\end{array}$ & $\begin{array}{l}\text { After } \\
36 \mathrm{M} \\
\text { Beta } \\
\text { CAR } \\
\end{array}$ \\
\hline 1 & $\begin{array}{l}\text { Africa } \\
\text { properties }\end{array}$ & $\begin{array}{l}\mathrm{BBB} \\
\mathrm{BBB}+\end{array}$ & 1.70 & 1.45 & -10.10 & 6.12 & -11.34 & 6.48 & -10.76 & 6.19 \\
\hline 2 & Aloni Hez & $\begin{array}{l}\mathrm{A} \\
\mathrm{A}+\end{array}$ & 0.92 & 1.03 & 8.03 & -1.41 & 7.41 & -1.08 & 8.73 & -1.51 \\
\hline 3 & $\begin{array}{l}\text { Clal } \\
\text { Insurance }\end{array}$ & $\begin{array}{l}\mathrm{BBB}+ \\
\mathrm{A}-\end{array}$ & 1.51 & 1.38 & -4.59 & 9.48 & -4.67 & 7.20 & -4.63 & 7.78 \\
\hline 4 & $\begin{array}{l}\text { Gazit } \\
\text { Globe }\end{array}$ & $\begin{array}{l}\mathrm{A}+ \\
\mathrm{AA}-\end{array}$ & 0.74 & 1.12 & -0.73 & -0.18 & -1.13 & 0.15 & -0.53 & -0.32 \\
\hline 5 & Big & & 0.88 & 0.8 & 0.38 & 2.62 & 0.77 & 2.46 & 1.02 & 0.63 \\
\hline 6 & Levinstein & $\begin{array}{l}\text { A- } \\
\text { A }\end{array}$ & 0.61 & 0.54 & 17.34 & 12.74 & 18.63 & 14.19 & 18.86 & 14.45 \\
\hline 7 & Gold & $\begin{array}{l}\text { BBB- } \\
\text { BBB }\end{array}$ & 0.26 & 0.32 & 13.50 & 2.89 & 14.16 & 7.09 & 14.10 & 6.75 \\
\hline 8 & $\begin{array}{l}\text { Barak } \\
\text { Capital }\end{array}$ & $\begin{array}{l}\text { BBB- } \\
\text { BBB }\end{array}$ & 1.17 & 1.25 & 0.43 & -2.48 & 0.65 & -3.80 & 0.75 & -4.43 \\
\hline 9 & $\begin{array}{l}\text { Edgar } \\
\text { Investment }\end{array}$ & $\begin{array}{l}\text { BBB } \\
\text { BBB }+\end{array}$ & 0.38 & 0.54 & 3.45 & -0.53 & 2.52 & 4.25 & 2.76 & 3.02 \\
\hline & Average & & 0.90 & 0.93 & 3.07 & 3.25 & 3.00 & 4.10 & 3.36 & 3.61 \\
\hline & $\begin{array}{l}\text { St. Dev } \\
\text { Max }\end{array}$ & & $\begin{array}{l}0.48 \\
1.70\end{array}$ & $\begin{array}{l}0.40 \\
1.45\end{array}$ & $\begin{array}{l}8.64 \\
17.34\end{array}$ & $\begin{array}{l}5.22 \\
12.74\end{array}$ & $\begin{array}{l}9.22 \\
18.63\end{array}$ & $\begin{array}{l}5.40 \\
14.19\end{array}$ & $\begin{array}{l}9.18 \\
18.86\end{array}$ & $\begin{array}{l}5.77 \\
14.45\end{array}$ \\
\hline & Min & & 0.26 & 0.32 & -10.10 & -2.48 & -11.34 & -3.80 & -10.76 & -4.43 \\
\hline
\end{tabular}

Notes: 1 . Before simple $\mathrm{CAR}=30$ days before the event Cumulative Abnormal Return. When abnormal return is the stocks daily returns minus the benchmark daily return 2 . After simple $C A R=60$ days after the event Cumulative Abnormal Return when abnormal return is the stocks daily returns minus the benchmark daily return. 3 . Before 12 months Beta $\mathrm{CAR}=30$ days before the event Cumulative Abnormal Return. When abnormal return is the stocks daily returns minus the required CAPM daily returns calculated with 12 month Beta. 4. After 12 months Beta CAR= 60 days after the event Cumulative Abnormal Return when abnormal return When abnormal return is the stocks daily returns minus the required CAPM daily returns calculated with 12 month Beta. 5. Before 36 months Beta CAR=30 days before the event Cumulative Abnormal Return. When abnormal return is the stocks daily return minus the required CAPM daily return calculated with 36 month Beta. 4. After 12 months Beta CAR= 60 days after the event Cumulative Abnormal Return when abnormal return When abnormal return is the stocks daily returns minus the required CAPM daily returns calculated with 36 month Beta.

Table 1 shows that out of the 9 examined stocks 6 have produced a positive CAR during the 30 days before the event for all three CAR calculations. This result suggests that the information of the rating changes has leaked to the financial markets before it was announced publicly. Results also show a positive CAR for 60 days after the event as follows: simple calculated CAR in 5 cases, 7 cases of positive CAR when the stock "Beta" was calculated for 12 months and 6 positive CAR when the "Beta" was calculated for 36 months. In four Cases, the 60 days abnormal return toped 5\%. Moreover, results show that the rating changes have significantly impacted the abnormal return changing them from negative to positive in only two cases: "Africa" and "Clal".

In order to observe the rating change on the socks returns I now accumulated the abnormal return without separating the 30 days before from the 60 days after the event and presented the results in Figure 1. 


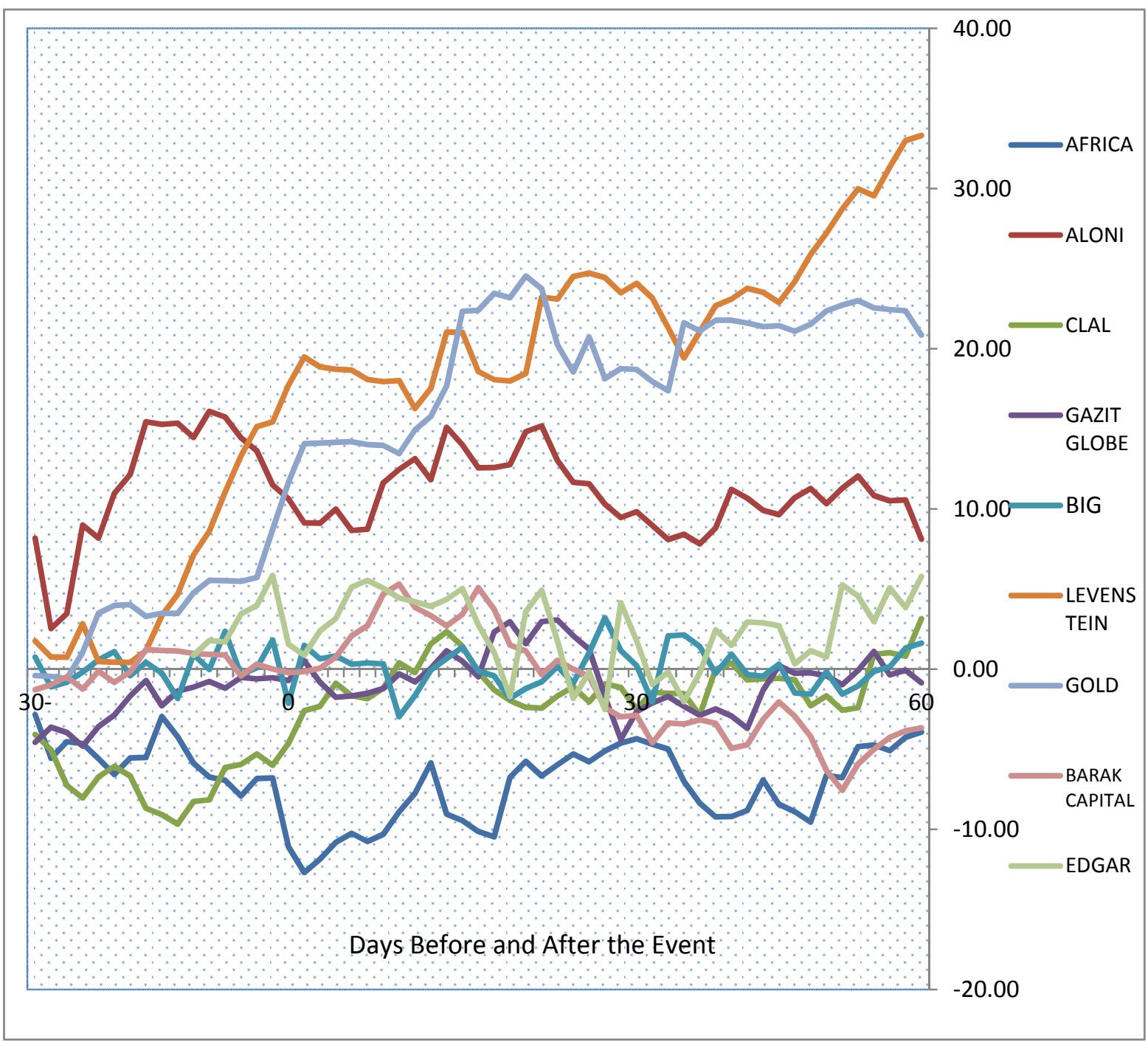

Figure 1. Cumulative abnormal return 30 days before the to 60 days after credit rating upgrade

Figure 1 shows that only in 4 cases an abnormal return has risen before and after the rating change, resulting in 33.3\%, 20.85\%, 1.65\% and 5.78\% CAR for "Levenstien","Gold", "Big" and "Edgar" respectively. When out of those stocks for only 3 stocks the CAR toped 5\%. For 2 stocks only ("Levenstien","Gold") the effect of the downgraded had lasted 60 days.

I now repeated my analysis for 9 stocks for which "Maalot" has decreased their credit rating. Results are summarized in Table 2. 
Table 2. Cumulative abnormal return (\%) 30 days before and 60 days after credit rating downgrade

\begin{tabular}{|c|c|c|c|c|c|c|c|c|c|c|}
\hline & & & 12 & & Before & After & Before & After & Before & After \\
\hline & Stock & Downgrades & months & months & simple & simple & $12 \mathrm{M}$ & $12 \mathrm{M}$ & $36 \quad \mathrm{M}$ & $36 \mathrm{M}$ \\
\hline & & From- & Beta & Beta & CAR & CAR & Beta & Beta & Beta & Beta \\
\hline & & to & & & & & CAR & CAR & CAR & CAR \\
\hline 1 & MASHBIR & BBB- & 0.26 & 0.45 & 18.69 & -9.27 & 20.76 & -9.20 & 20.22 & -9.22 \\
\hline & 365 & BB & & & & & & & & \\
\hline 2 & ELBIT & BBB & 1.74 & 1.69 & -7.6 & 22.08 & -5.02 & 18.98 & -5.20 & 19.19 \\
\hline & IMAGING & B & & & & & & & & \\
\hline 3 & & $\mathrm{AA}+$ & 0.86 & 1 & 7.73 & 16.47 & 8.11 & 16.30 & 7.73 & 16.47 \\
\hline & BEZEK & AA & & & & & & & & \\
\hline 4 & KARDEN & BBB- & 1.93 & 1.48 & -11.26 & -37.48 & -13.05 & -36.32 & -13.15 & -36.26 \\
\hline & N.V & BB & & & & & & & & \\
\hline 5 & SKYLKS & $\mathrm{CC}$ & 1.51 & 1.25 & -1.33 & -55.62 & -1.20 & -56.28 & -1.26 & -55.94 \\
\hline & & SD & & & & & & & & \\
\hline 6 & MELISRON & AA- & 0.98 & 0.81 & 2.35 & 2.90 & 2.28 & 2.91 & 1.77 & 3.04 \\
\hline & & $\mathrm{A}+$ & & & & & & & & \\
\hline 7 & TELDOR & A & 0.22 & .45 & 9.42 & 30.57 & 7.92 & 29.66 & 7.79 & 29.58 \\
\hline & & A- & & & & & & & & \\
\hline 8 & I.D.B & $\mathrm{CC}$ & 1.74 & 1.64 & -14.29 & -21.79 & -14.01 & -23.77 & -14.05 & -23.50 \\
\hline & & SD & & & & & & & & \\
\hline 9 & CELLCOM & AA- & 0.86 & 0.83 & 6.05 & 21.25 & 5.93 & 21.41 & 5.91 & 21.44 \\
\hline & & $\mathrm{A}+$ & & & & & & & & \\
\hline & Average & & 1.12 & 1.06 & 1.08 & -3.43 & 1.30 & -4.03 & 1.08 & -3.91 \\
\hline & St. Dev & & 0.64 & 0.47 & 10.72 & 29.80 & 11.05 & 29.50 & 10.92 & 29.42 \\
\hline & Max & & 1.93 & 1.69 & 18.69 & 30.57 & 20.76 & 29.66 & 20.22 & 29.58 \\
\hline & Min & & 0.22 & 0.45 & -14.29 & -55.62 & -14.01 & -56.28 & -14.05 & -55.94 \\
\hline
\end{tabular}

Notes: 1 . Before simple $\mathrm{CAR}=30$ days before the event Cumulative Abnormal Return. When abnormal return is the stocks daily returns minus the benchmark daily return 2 . After simple $\mathrm{CAR}=60$ days after the event Cumulative Abnormal Return when abnormal return is the stocks daily returns minus the benchmark daily return. 3 . Before 12 months Beta $\mathrm{CAR}=30$ days before the event Cumulative Abnormal Return. When abnormal return is the stocks daily returns minus the required CAPM daily returns calculated with 12 month Beta. 4. After 12 months Beta CAR= 60 days after the event Cumulative Abnormal Return when abnormal return When abnormal return is the stocks daily returns minus the required CAPM daily returns calculated with 12 month Beta. 5. Before 36 months Beta CAR=30 days before the event Cumulative Abnormal Return. When abnormal return is the stocks daily return minus the required CAPM daily return calculated with 36 month Beta. 4. After 12 months Beta CAR= 60 days after the event Cumulative Abnormal Return when abnormal return When abnormal return is the stocks daily returns minus the required CAPM daily returns calculated with 36 month Beta.

The results summarized in Table 2 are interesting: when the firm's bond is downgraded from BBB- or a lower grade to $\mathrm{BB}$ and lower grade which is considered Non-Investment grade (speculative), then a negative abnormal return was found during the 60 days after the event. Otherwise a downgrade of the firm's bond rating does not cause abnormal return after 60 days. It is worth noticing that out of the 9 cases in 4 cases the information of the downgrade have probably leaked to the financial markets before the official publication date. In order to observe the rating change on the socks returns, I accumulated again the abnormal return without separating the 30 days before from the 60 days after the event and presented the results in Figure 2. 


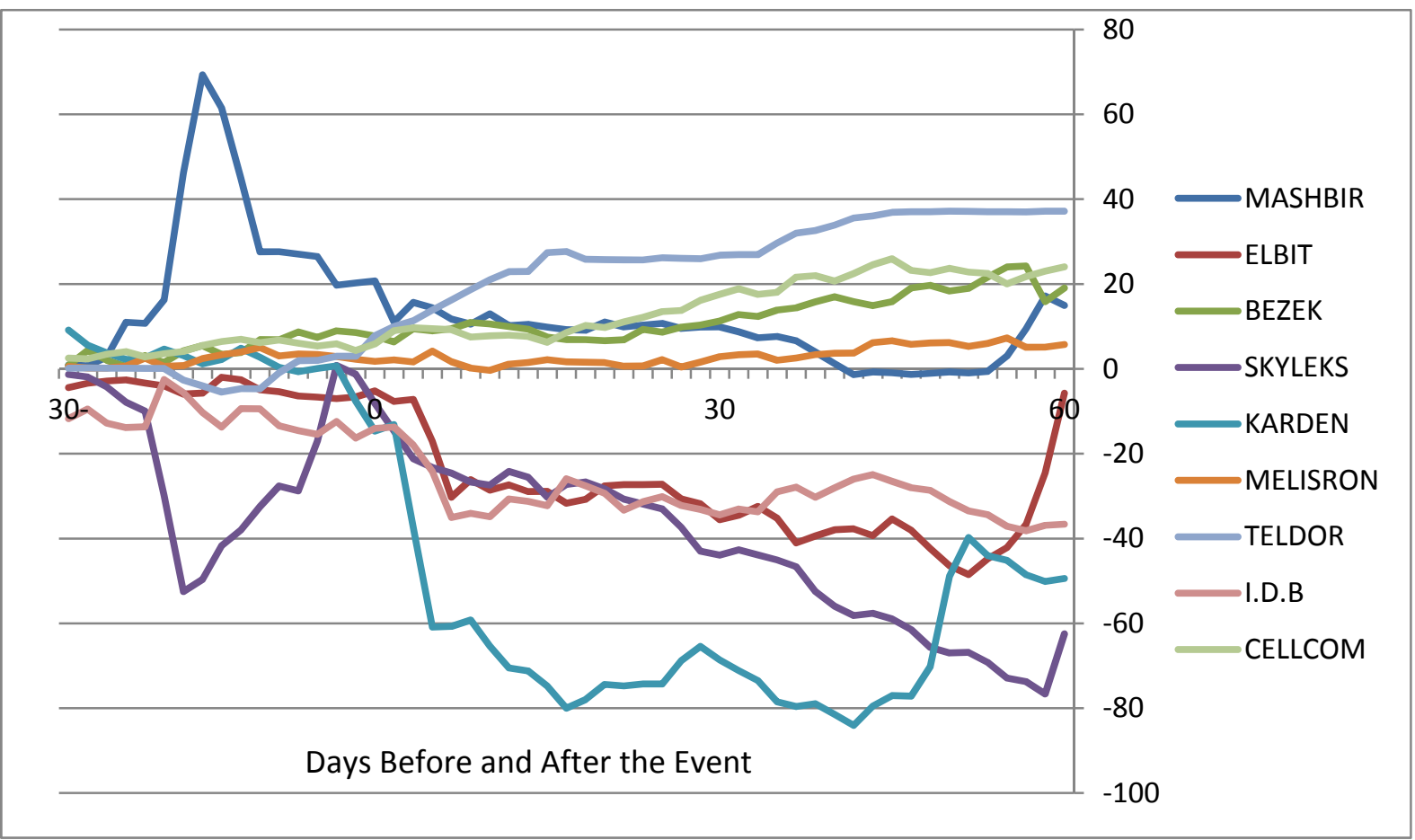

Figure 2. Cumulative abnormal return 30 days before the to 60 days after credit rating downgrade

Graph 2 show clearly that after the official announcement date of the downgrade, a negative abnormal return has been started to be accumulated in four stocks: "Elbit", "I.D.B","Skyleks", "Karden" and "Mashbir". Graph 2 also shows that the downgrade effect is diminished after 45 days.

\section{Summary and Conclusions}

In the following research I have studied how bond rating changes that was conducted by Israel leading rating agency "Maalot" is affecting the firm's stocks abnormal returns. In order to do so I have examined 9 bonds upgrades and 9 downgrades from December 2012 until October 2013. For each of the stocks I have calculated three times abnormal return 30 days before and 60 days after the event. The first was a simple abnormal return which was calculated simply by subtracting the stock's daily return from the benchmark (Tel-Aviv 100 Index) returns. Secondly, I have calculated 12 month and 36 months stocks "Betas" and used them to calculate abnormal return utilizing the CAPM. The triple check purpose was to examine any differences among the results that were not founded a posteriori.

Results show that bond's rating downgrades has a more significant effect on the socks abnormal return than upgrades. This is especially true for bonds that were downgraded from Lower-medium grade to Non- Investment grade. Moreover, the downgrade effect on the stock price is diminishing after 45 days.

\section{References}

Asquith, P., Beatty, A., \& Weber, J. (2005). Performance pricing in bank debt contracts. Journal of Accounting and Economics. 40, 101-128. http://dx.doi.org/10.1016/j.jacceco.2004.09.005

Bar-Isaac, H., \& J. Shapiro. (2012). Ratings Quality over the Business Cycle. Journal of Financial Economics, 108(1), 62-78. http://dx.doi.org/10.1016/j.jfineco.2012.11.004

Beaver, W.H., Shakespeare, C., \& M.T. Soliman. (2006). Differential Properties in the Ratings of Certified vs. Non-Certified Bond Rating Agencies. Journal of Accounting and Economics, 42(2), 303-334. http://dx.doi.org/10.1016/j.jacceco.2006.06.002

Becker, B., \& T. Milbourn. (2011). How Did Increased Competition Affect Credit Ratings? Journal of Financial Economics, 101, 493-514. http://dx.doi.org/10.1016/j.jfineco.2011.03.012

Bolton, P., Preixas, X., \& Shapiro, J. (2012). The Credit Ratings Game. Journal of Finance, 67, 85-111. http://dx.doi.org/10.1111/j.1540-6261.2011.01708.x 
Bongaerts, D., K. J. M. Cremers, \& W. N. Goetzmann. (2012). Tiebreaker: Certification and Multiple Credit Ratings. Journal of Finance, 67, 113-152. http://dx.doi.org/10.1111/j.1540-6261.2011.01709.x

Borrus, A. (2002). Opening up the credit rating club? BusinessWeek, December 9.

Camanho, N., P. Deb, \& Z. Liu. (2010). Credit Rating and Competition. Working paper, London School of Economics.

Cantor, R., \& Packer, F. (1995). The credit rating industry. The Journal of Fixed Income, 10-34. http://dx.doi.org/10.3905/jfi.1995.408153

Djankov, S., La Porta, R., Lopez-di-Silanes, F., \& Shleifer, A. (2012). Regulation of entry. Quarterly Journal of Economics, 117, 1-37. http://dx.doi.org/10.1162/003355302753399436

Doyle, J. (2004). Credit, risk measurement and pricing in performance pricing-based debt contracts. Working Paper, University of Utah.

Ericsson, J., \& O. Renault. (2002). Liquidity and credit risk. working paper, McGill University.

Grier, P., \& S. Katz. (1976). The differential effects of bond rating changes among industrial and public utility bonds by maturity. Journal of Business, 49, 226-239. http://dx.doi.org/10.1086/295833

Griffin. P., \& A. Sanvincente. (1982). Common stock returns and rating changes: A methodological comparison. Journal of Finance, 37, 103-119.

Hunt, I. (2002). Testimony of Isaac Hunt Jr., commissioner United States Securities and Exchange Commission, before the committee on Governmental Affairs United States Senate.

Kaplan R. S., \& G. Urwitz. (1979). Statistical model of bond rating: A methodological inquiry. The journal of business, 52(2). http://dx.doi.org/10.1086/296045

Longstaff, F., S. Mithal, \& E. Neis. (2005). Corporate yield spreads: Default risk or liquidity? New evidence from the credit- default swaps market. Journal of Finance, 60, 2213-2253. http://dx.doi.org/10.1111/j.1540-6261.2005.00797.x

Mathis, J., J. McAndrews, \& J.C. Rochet. (2009). Rating the Raters: Are Reputation Concerns Powerful Enough to Discipline Rating Agencies? Journal of Monetary Economics, 56, 657-674. http://dx.doi.org/10.1016/j.jmoneco.2009.04.004

Pinches, G., \& Singleton, J. (1978). The adjustment of stock prices to bond rating changes. Journal of Finance 33, 29-44. http://dx.doi.org/10.1111/j.1540-6261.1978.tb03387.x

Wakeman, L. (1978). Bond rating agencies and the capital markets. Working paper, University of Rochester, Rochester, NY.

Watts, R. (1977). Corporate financial statements, a product of the market and political processes. Australian Journal of Management, 2, 53-75. http://dx.doi.org/10.1177/031289627700200104

Watts, R. (2003). Conservatism in accounting part I: explanations and implications. Accounting Horizons, 17, 207-221. http://dx.doi.org/10.2308/acch.2003.17.3.207

Weinstein, M. (1977). The effect of a rating change announcement on bond price. Journal of Financial Economics, 5, 329-350. http://dx.doi.org/10.1016/0304-405X(77)90042-3

Xia, H. (2012). Can Competition Improve the Information Quality of Credit Ratings? Working paper, University of Texas at Dallas.

\section{Notes}

Note 1. See for example Grier and Katz (1976).

Note 2. A subsidiary of Standard and poor founded in 1995.

Note 3. David Hodeck was the head of that committee.

Note 4. These local rating agencies use their parent rating systems."Maalot" uses the S\&P scale: AAA, AA, A etc. While "Midrug "uses Moddy's scale: Aaa,Aa1, Aa2 etc. "Maalot" was founded in 1995 while "Midrug" in 2003.

Note 5. Not including changing rating prospects.

Note 6. The "Beta" was calculated using the CAPM formula. 